\title{
Consumer, Investor, and Combined Reactions Following Product-Harm Crises
}

\author{
Robert D. Evans, Jr. \\ Texas A\&M International University \\ Western Hemispheric Trade Center 206C \\ A.R. Sanchez, Jr. School of Business \\ Laredo, TX 78041
}

Tel: 956-326-2846_E-mail: robert.evans@tamiu.edu

Received: July 4, 2015 Accepted: August 4, 2015 Published: October 1, 2015

doi:10.5296/jmr.v7i5.8066

URL: http://dx.doi.org/10.5296/jmr.v7i5.8066

\begin{abstract}
Using a series of Toyota automotive recalls as the context, this study examines reactions by consumers, investors, and reports on a combined measure to capture the overall effect of the recalls on the firm. Following the recalls, consumer sales returned to pre-recall levels quickly, however, investors immediately punished the firm with negative abnormal returns of between -14.16 and $-16.04 \%$ over the longest event windows examined. A combined measure designed to capture consumer and investor reaction shows that the overall brand value of Toyota declined by $16 \%$ in the year following the announcement of the product-harm crises. Investor and consumer reaction was different following the recalls. Managerial implications are discussed.
\end{abstract}

Keywords: Econometrics, firm behavior, consumer protection, marketing, consumer behavior. 


\section{Introduction}

Understanding the distinct value which consumers and investors contribute to the overall wealth of the firm is a struggle for many managers to evaluate and understand. The primary focus of many firms' communication and advertising strategies emphasize reaching the customer in an effort to raise awareness of the firms' product line and to drive consumer sales. However, this perspective neglects the value which investors contribute to the firm and leads to the question of whether a firm's communication and advertising strategy should focus on the consumer or the investor? The consumer provides direct capital to the firm through sales while the investor provides capital for investment in projects which have a positive net-present value as well as research and development and operating costs (Evans,2010). Because it is difficult to measure an aggregated response to a firm-related initiative or event, the focus of most studies disaggregate these groups and turn their attention to either the consumer or the investor, with a majority of studies focusing on the consumer.

Consumers have long been the primary focus of marketing literature, most often focusing on attitudes, beliefs, and behaviors. However, examination of the investor as a consumer has only recently become well established in marketing literature (e.g., Deitz, Evans, \& Hansen, 2013; Luo \& Bhattacharya, 2009). Despite these advances, studies often wholly focus on one of two groups; consumers or investors. Consumers are most often studied through their attitudes and reactions to various stimuli (Stafford, 2000), situational influences (Collier \& Sherrell, 2010), or satisfaction (Jack \& Powers, 2013). Conversely, studies examining the investor most often examine their reactions to various events or stimuli through changes in firm stock price (Markovitch \& Golder, 2008) or firm shareholder wealth (Bharadwaj et al., 2011 ) to gauge reaction to firm news (negative or positive) (Evans, 2010), announcement of dividends (Fama, 1980), or general market conditions (Deitz, Evans, \& Hansen, 2013). This could lead to the inference that shareholders and consumers might be controlled by and use different theoretical bases in their decision-making processes. The advent of this interface has resulted in the acceptance in marketing literature of models which have traditionally been reserved for economic, financial, and accounting studies. Given that previous studies examine consumers and investors separately; this study seeks to address this deficiency and expand the literature by examining the reaction of both of these groups following a series of well-publicized product-harm crises (PHCs) affecting Toyota Motor Corporation (Toyota), and investigates how different theories control each of these distinct groups to better understand their reactions.

This paper seeks to answer three questions as they relate to consumers and investors. First, the question of how consumers react to PHCs is addressed in the marketing literature (e.g. Diwar \& Pillutla 2010; Laufer, Gillespie, \& Silvera, 2009). However, previous marketing research examining PHCs primarily uses controlled conditions in a laboratory setting with hypothetical brands and situations (Zhao, Zhao, \& Helsen 2011). By examining genuine consumer reaction to a real PHC, firms should be able to better understand the effect on users of their products and the implications for sales following a PHC. Further, this study examines the reaction of non-users as well, assessing whether or not prior interaction with the brand under investigation affects consumers' purchase intentions and attitude towards Toyota. 
Second, examination of a central character in firm success and an increasingly important focus of marketing literature; the investor. As marketing literature has moved to understand the role of the investor in the overall financial performance of the firm, studies have shown that they react to various firm events or metrics. Studies have shown that brand quality (Bharadwaj, Tuli, \& Bonfrer, 2011), customer satisfaction (Anderson, Fornell, \& Mazvancheryl, 2004) and event sponsorship (Deitz, Evans, \& Hansen, 2013; Cornwell \& Pruitt, 2009) have an effect on shareholder wealth. This study builds on the marketing-finance literature by examining how investors react following a PHC via abnormal returns to shareholder wealth. While most studies investigating the effects to shareholder wealth examine abnormal returns over the short-run event-windows, this study extends the literature by investigating whether the results are persistent and long-lasting via buy-and-hold abnormal returns.

Finally, this study investigates a combined measure designed to capture both, consumer and investor reactions to a single event which has the potential to move these groups to action. Because previous studies in marketing literature examine only one of those two stakeholder groups, we turn to the practitioner world in an effort to find a measure suitable to capture the overall effect. By accounting for the reaction of both of these groups, firm managers should be better able to understand the aggregated effect of a PHC on the firm.

The rest of the paper is organized as follows. The study context is elaborated on and described in-depth, including dates of the PHCs and the vehicles involved. Drawing on marketing literature, a review of past research and contexts as it relates to PHCs is further discussed. Since this article consists of three individual studies examining reactions by consumers, investors, and a combined measure, each study section contains theoretical development and hypotheses. Finally, results, managerial implications, and future research are discussed.

\section{Study Context}

In January of 2010, Toyota announced a series of recall announcements related to the safety of their most popular vehicles: the Camry, Corolla, Prius, and the Tundra (Mittal, Dholakia, $\&$ Sambandam, 2010). These recalls led to speculation by financial news networks of a rapid decline in the financial stability and future sales of Toyota vehicles (CNN, 2010). Despite this speculation, whether a post-recall Toyota was going to flourish or flounder was not clear. A study conducted by Mittal, Dholakia, \& Sambandam (2010) states that Toyota had avoided damage to their reputation because of the post-recall attitudes of Toyota owners. Despite this assertion, their study neglects to take into account the contribution that non-Toyota owners and shareholders make to the overall value and reputation of the firm. As can be seen in Figure 1, consumers and investors reacted quite differently following the announcement of the recalls, suggesting that these two groups are controlled by, and require the application of different theoretical foundations in order to understand post-recall behavior. This assumption is due to the fact that consumer sales returned quickly to pre-recall levels while firm stock price declined rapidly and remained at a lower level relative to pre-recall levels. This study seeks to help understand this behavior and examine consumer and investor reactions to these 
recalls, as well as to examine a combined measure that captures the overall effect of the recalls on the firm.

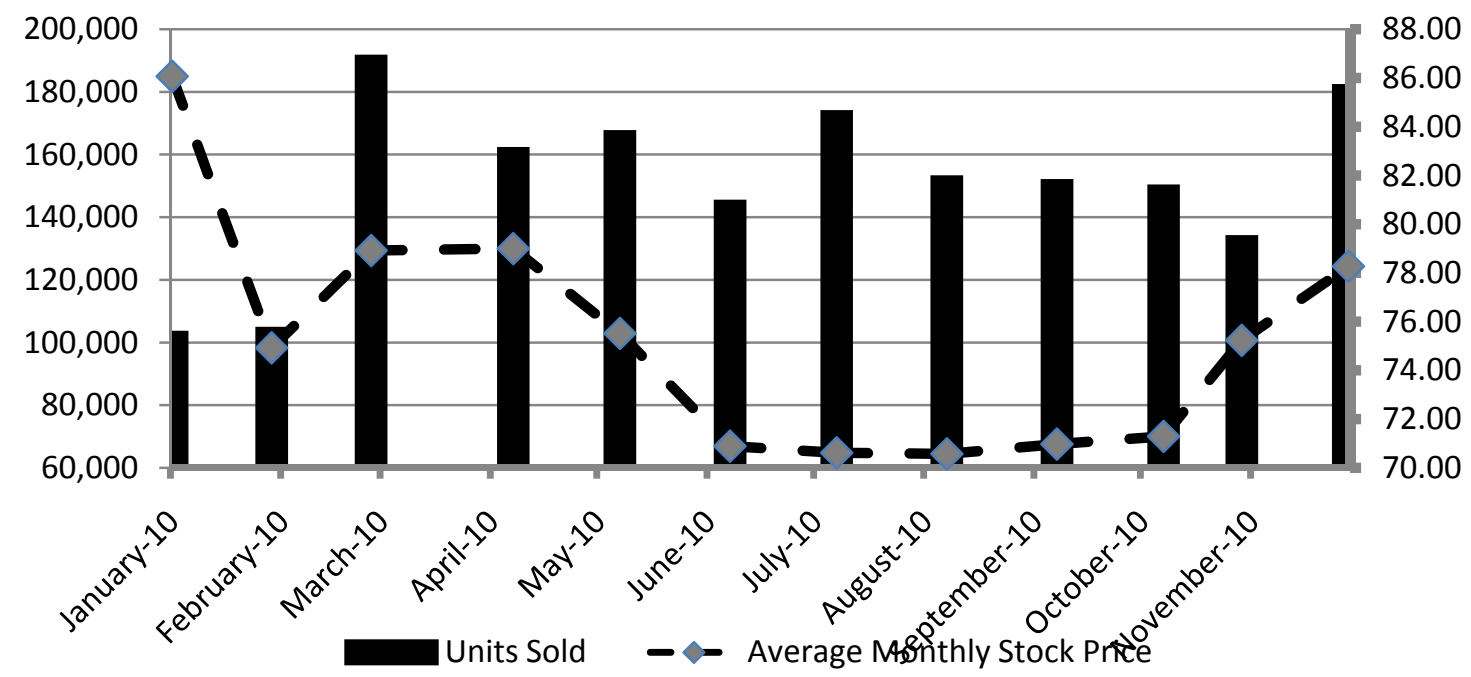

Figure 1. Toyota Sales and Stock Price, 2010

\section{Product-Harm Crises}

Product-harm crises (PHCs) are well-publicized events that involve defective, faulty, or manipulated products or services that become a danger to the individual who uses them (Dawar \& Pillutla, 2000). Chen, Ganesan, \& Liu (2009) explain that these types of events happen when a product or service fails to meet a minimum safety standard, is defective to the point that it could cause serious physical or mental harm, the risk associated with the use of the product or service creates an unreasonable risk of serious injury or death, or, fails to meet minimum governmental regulatory standards or voluntary standards set forth by the industry within which the firm operates and often requires immediate corrective action (Krystek, 1987, p. 6).

Product-harm crises, which include product recalls, have greatly increased in the past few decades according to the Consumer Product Safety Commission (Kalaignanam Kushwaha, \& Eilert, 2013). For example, in 2000, over 175 deaths and 700 serious injuries were attributed to a series of defective tires produced by Firestone (Total Recall, 2006). Firestone did not manufacture the tires to meet the safety standards of the US Department of Transportation's National Highway Transportation Safety Administration (NHTSA, 2000). Consequently, the tires fell apart at speeds within legally stated speed limits. This defect led to a recall of 6.5 million tires at a direct cost to the firm in excess of $\$ 300$ million (Total Recall, 2006). The failure was so severe that it left the firm with massive financial losses through direct replacement cost of the defective product, a series of civil lawsuits, a drop in firm stock price, and, led to the demise of a decades old supply chain relationship between Firestone and the Ford Motor Corporation. In addition to the direct costs, Firestone suffered an estimated $\$ 400$ million in lost sales as a result of the incident (Deadly Combination, 2001). 
Toyota's PHCs culminated in January 2010 with a series of automotive recalls affecting in excess of 5 million vehicles worldwide (Table 1). The primary reasons for the recalls were accelerator pedals, floor mats, and anti-lock brake systems in their most popular vehicles: the Camry, Corolla, Prius, and the Tundra (Mittal, Dholakia, \& Sambandam, 2010). Based on this news, market experts, the business media, and various news outlets predicted a rapid decline in Toyota's financial and sales fortunes (Tough Times for Toyota, 2011). Prior to the recall crisis, Toyota was generally viewed quite favorably by consumers and investors alike based on their sales and stock performance. The independent product ranking firm Interbrand valued their brand at $\$ 31.3$ billion in 2009 , ranking them as the eighth strongest brand in the world (Best Global Brands, 2009).

Table 1. Recall Event Dates for Toyota Recalls

\begin{tabular}{llll}
\hline & Country & $\begin{array}{l}\text { Number of } \\
\text { Vehicles }\end{array}$ & Reason for Recall \\
\hline \multirow{2}{*}{ January 21, 2010 } & United States & 2.1 million & Accelerator Pedal \\
January 27, 2010 & United States & 1.1 million & Floor mat \\
January 29, 2010 & China and various European countries & 1.8 million & Accelerator Pedal \\
\hline
\end{tabular}

\section{Theoretical Development and Hypotheses}

To understand how Toyota's PHCs influence consumer, financial, and combined consumer-financial measures, this study examines each group in three separate studies that use different theoretical bases. Theoretical foundations and hypotheses for each study are discussed below.

\subsection{Consumers}

To examine the consumer-based effects of the product recall, the theory of involvement (Zaichkowsky, 1985) is deemed as appropriate and is frequently used in the marketing literature to understand consumer behavior. Involvement generally refers to the personal relevance of an object, value, or interests to an individual (Zaichkowsky, 1985). Specifically, involvement most often relies on the personal importance or relevance of the purchase or consumption of a product or service (Engel \& Blackwell, 1982). To more richly develop the concept of involvement, Jain \& Srinivasan (1990) further define involvement as an "unobservable state of motivation, arousal, or interest evoked by a particular stimulus." Additional studies in the marketing literature also show that the level of consumer involvement, most often defined as high- or low-involvement, has a direct effect on the evaluation of products and services and brand preference (Bloch Sherrell, \& Ridgway, 1986), as well as exerting influence in the consumers' decision-making process (Suh \& Yi, 2006). Churchill \& Suprenant (1982) acknowledge that the level of consumer involvement might have a central role beyond the level of satisfaction a consumer experiences pre- and 
post-purchase. They also explain that consumers with relatively high levels of involvement could experience positive attitude changes towards the product or service, engage in repeat purchases, and exhibit higher levels of brand loyalty than consumers with relatively low levels of involvement.

As for the influence of involvement on consumers who have prior experience with the brand, product, or service that is at the center of a PHC, they can experience sudden and large shifts in their opinions, thoughts, and feelings toward the firm (Dawar \& Pillutla, 2000). These opinions, thoughts, and feelings are most often out of the control of management and are prone to the influence of extraneous information such as news stories, consumer reports, and word-of-mouth influence. However, certain groups are less prone to the influence of this type of news. These groups mostly have a high level of involvement with the firm. In the case of this study, those consumers that display a high level of involvement with Toyota and their products are Toyota owners. Antil (1984) observes that the level of involvement of an individual and his or her decision to purchase or remain loyal to a particular brand of automobile is quite important to that individual. Those individuals who have previous involvement with a brand might not engage in extensive external searches of news articles, word-of-mouth interactions, or the Internet, and discount negative news about the brand or product (Antil 1984). Because of the relevance of the large financial and emotional investment to the owners, this study logically infers that current Toyota owners possess a higher level of involvement with the Toyota brand than non-Toyota owners. Also, Zhao, Zhao, \& Helsen (2011) find support that following a PHC, heavy users or frequent purchasers of a brand have less variance in their perceived quality of a brand than light users of the brand, meaning that those who have a higher level of involvement via their purchasing and ownership patterns are less swayed by the negative news of events such as the Toyota automotive recalls. Zhao, Zhao, \& Helsen (2011) further find that for those individuals who have lower levels of involvement, the PHC reinforces prior beliefs about the brand that in turn, the study speculates might lead to a decrease in the perception of the quality of the brand. Thus, this study hypothesizes that:

H1: Consumers' attitude toward Toyota products is higher for high-involvement consumers (Toyota owners) than for low-involvement consumers (non-Toyota owners) following the Toyota automotive recalls.

H2: Consumers' purchase intentions towards Toyota products are higher for high-involvement (Toyota owners) consumers than for low-involvement consumers (non-Toyota owners) following the Toyota automotive recalls.

\subsection{Investors}

For investors, this study uses the efficient-market theory (Fama, 1970) to understand investor behavior, which is extensively applied in the fields of economics, finance, accounting, and more recently in marketing (e.g., Evans, 2010; Deitz, Evans, \& Hansen, 2013). The theory was developed by Eugene Fama in his 1965 dissertation thesis while at the University of Chicago. His thesis suggests that stock prices are unpredictable and follow a "random walk" (Fama, 1965). In successive papers, Fama explains that the efficient-market theory has 
further implications in that the stock price is reflective of all market information and that investors have knowledge of that market information, have evaluated the strength of that information, and, in turn, make their investment decisions in an expeditious manner (Fama, 1970). The efficient-market hypothesis has been criticized by the accounting, economics, and finance literature for its failure to incorporate the influence of non-market news, the personal preferences of the investor, and the discounting of the power of the intangible qualities of a firm. Despite these criticisms, the theory remains the current standard in the literature for examining investor behavior. As such, this study adopts the efficient-market theory to examine investor behavior.

During a PHC, investor behavior plays a central role in capturing the impact on the investor-based measure of the firm's stock price that, in turn, dictates the financial value of a firm as measured by shareholder wealth (Dawar \& Pillutla, 2000). For example, PHCs and product recalls can exert harsh financial punishments on firms resulting in negative effects on their revenues, stock prices, and market share (e.g., Rhee \& Haunschild 2006; Van Heerde, Helsen, \& Dekimpe 2007). Chen, Ganesan, \& Liu (2009) point to the example of the pharmaceutical sales and research and development firm Merck that initiated a recall in 2004 of its arthritis drug Vioxx. Doctors prescribed the drug to more than 20 million people as a pain reliever for arthritis before finding out later that it was responsible for an increased risk of heart attack and stroke in individuals taking the drug. The speculation was that the drug might have been responsible for 27,000 deaths as well as contributing to coronary artery disease in another 140,000 users. This recall led to a single day drop in Merck's stock price from $\$ 45.07$ to $\$ 33.00$, or a $27 \%$ drop in value. Merck also suffered an additional cost of $\$ 6$ billion in litigation-related expenses. Furthermore, because Merck had 2.219 billion shares outstanding at the time of the recall, the loss in shareholder value alone approached \$27 billion on the day of the recall announcement. Therefore, because investors could react negatively to news of a product recall or a PHC, this study hypothesizes that:

H3: Investor reaction to each of the Toyota automotive recalls in January 2010 results in negative abnormal returns to the firm's stock price on the trading days surrounding the recall announcements.

From an investor perspective, PHCs can jeopardize enduring relationships with the stock and have negative performance consequences that linger long after the crisis (Van Heerde, Helsen, \& Dekimpe, 2007). More importantly, negative firm news and events are more persistent than positive firm news and information (Carlston \& Skowronski, 2005). Therefore, in addition to capturing the short-term effect on investor behavior hypothesized above, the study uses a long-term measure, the buy-and-hold abnormal returns (BHARs), to capture the reaction of investors to the Toyota recalls examined in this study. Therefore, this study hypothesizes that:

H4: Investor reaction to the January 2010 Toyota automotive recalls is persistent and results in negative buy-and-hold abnormal returns (BHARs). 


\subsection{Combined Measure}

In an effort to better understand the shared effect of consumer and investor reactions to the Toyota PHC recalls, the study requires a combined measure that can capture the post-recall effect on these two groups. However, a generally accepted measure to capture the effect of consumer and investor behavioral responses does not exist in the marketing literature. Because of this fact, the study turns to an organization that specializes in a practitioner-based approach to measure the overall value of a firm by using both consumer- and investor-based measures: Interbrand.

Interbrand is an independent research firm that has developed a brand valuation methodology that evaluates and measures consumer and investor contributions to the firm's brand value. This measure has been used and generally accepted by Fortune 500 companies and other firms worldwide for almost 30 years. Their methodology uses yearly consumer- and investor-based measures that contribute to the overall value of the firm that result in a single measure of brand valuation to rank the firm relative to others. The Interbrand methodology incorporates three different measures to create the final brand valuation measure: 1) a financial analysis that equals the overall financial return to the firms' investors and is referred to as the after-tax operating profit; 2) the role of brand that measures the portion that the brand contributes to the consumer's purchase decision, which includes price, convenience, and product features; 3 ) brand strength that measures the ability of the brand to create loyalty and generate future demand and profit for the firm. These three measures possess the ability to capture and explain on a yearly basis the effects of events that transpired during the year on consumers and investors while capturing the corresponding effects that these events have on the brand and brand value of the firm as expressed by consumer and investor behaviors. Because this measure captures both, the study hypothesizes that:

H5: The Interbrand Brand Equity Index year-over-year measure will decrease for Toyota from 2009 to the end-of-year measure for the year of the recalls, 2010.

\section{Methods}

\subsection{Consumers}

To examine the effect and test the proposed hypotheses of PHCs on consumers, a survey instrument was designed to captures consumers' attitudes and purchase intentions towards Toyota's product line, demographic information, as well as their current ownership status of a Toyota automobile. The survey instrument was administered through an online commercial survey site to owners and non-owners in the month following the announcement of the recalls under study. The survey was administered to residents of the United States, Mexico, and China. The survey produced a total of 327 responses, and, after eliminating unusable surveys due to missing data and those who weren't aware of the Toyota recall, produced 246 usable responses. Fifty-three percent of the respondents were female and $84.9 \%$ fell between the ages of 18-49. Ninety-five respondents were from the U.S., 74 from Mexico, and 77 from China. Lastly, $25.2 \%$ of the respondents currently owned a Toyota while $74.8 \%$ owned an 
automobile other than a Toyota. There was no incentivization, monetary or otherwise, provided for participation in the survey.

\subsubsection{Consumer Attitudes}

In order to assess consumer attitudes following the announcement of the Toyota recalls, respondents were asked, "Since you have become aware of the Toyota recall, how has that made you feel about Toyota automobiles?" Attitudes were assessed using a five-point Likert scale $(1=$ 'very favorable', 5 = 'very unfavorable'). The scale was adapted from Shimp \& Sharma (1987) and the wording was changed to fit the current study.

\subsubsection{Purchase Intentions}

The question assessing survey participants' purchase intentions, "The next time you decide to buy or lease a vehicle, how likely are you to buy a Toyota?" measured their willingness to purchase a Toyota vehicle, was assessed using a five-point Likert scale ( 1 = 'very unlikely', 5 = 'very likely'). The scale was adapted from Shimp \& Sharma (1987) and the wording was changed to fit the current study.

\subsection{Investors}

Because the best and most commonly used measure to capture the investors' reaction to internal or external events is the firm's stock price (Deitz, Evans, \& Hansen, 2013), data for the stock price are gathered from the Center for Research in Security Prices (CRSP) database via the Wharton Research Data Services (WRDS). Data for dates prior to and following the PHCs are gathered in order to apply the appropriate methodology to examine the hypotheses.

To capture the effects on the stock price and shareholder value, event-study methodology is broadly applied in the finance, economics, and accounting literature, and more recently in the marketing literature (e.g., Cornwell, Pruitt, \& Clark, 2005; Evans, 2010). This study follows previous marketing literature and applies event-study methodology to examine effects to the shareholder. This methodology is designed to measure the extent of the effect of an unanticipated event on firm stock prices. The underlying theory that supports the use of the event study methodology is the efficient-market hypothesis (Fama, 1970). The basis of this theory is that the firm's stock price reflects and incorporates the present value of all future cash flows expected to be earned by the firm and that the stock price reflects all available information that could influence the firm's current and future profitability. As unexpected and new information is made available to the market, the idea is that investors will then judge the quality and strength of that information and react accordingly. For example, if an investor believes that the information has the potential to have an effect on a firm's current or future profitability, the stock price will change quickly to absorb and incorporate that information. Brown \& Warner (1985) explain that the magnitude of the change, relative to the pre-event price is reflective of the economic value of that event (Agrawal \& Kamakura, 1995).

The standard approach to event study methodology is the use of a regression model to predict the expected returns for the firm based on an estimation period preceding the unanticipated 
event. Based on these expected returns, the abnormal returns (i.e., residuals) are calculated as the difference between the observed and expected returns predicted by the regression model. These abnormal returns are then aggregated and used to perform a statistical test to determine whether or not the abnormal returns are significant in relation to the expected returns. The use of this methodology rules out the use of accounting-based measures that have been criticized for their ability to be manipulated and not always accurate indicators of the firm's performance (Evans, 2010).

In the case of the recalls of various Toyota vehicles, they were unexpected events that provided new information to the marketplace that had the potential to have an effect on the firm's current and future cash flows and profitability. Due to these announcements, investors could immediately judge the impact of this news and that judgment could be reflected in the firm's stock price and returns. Because of this, the economic consequences of the recalls associated with Toyota's vehicles can be determined.

\subsection{Combined Measures}

As previously explained, I use Interbrand's brand valuation measure to examine the combined consumer and investor measure for this study. Since this measure is used by practitioners, including Fortune 500 companies, and has been in existence for almost 30 years, I feel as though the measure is appropriate and accurately captures the measure under investigation. Further explanation of the methodology can be found at www.interbrand.com.

\section{Analysis and Results}

\subsection{Consumer Results}

\subsubsection{Consumer Attitudes}

An independent-sample t-test is used to test H1, that consumers' attitude toward Toyota products is higher for high-involvement consumers (Toyota owners) than for low-involvement consumers (non-Toyota owners) following the Toyota automotive recalls. It was found that there is a significant difference between high-involvement consumers (Toyota owners) than for low-involvement consumers (non-Toyota owners) $(\mathrm{t}=-6.49$, $\mathrm{df}=223, \mathrm{p}$ $<0.001)$. Toyota owners $(\mathrm{M}=2.86, \mathrm{SD}=0.35)$ report significantly higher levels of post-recall attitudes with the Toyota brand than the non-Toyota owners $(\mathrm{M}=2.36, \mathrm{SD}=$ 0.85). These results show support for $\mathrm{H} 1$ that consumers' attitudes towards Toyota are higher for high-involvement consumers than consumers with low levels of involvement following the Toyota automotive recalls.

\subsubsection{Purchase Intentions}

An independent-sample t-test is also used to test H2, that consumers' purchase intentions towards Toyota products are higher for high-involvement (Toyota owners) consumers than for low-involvement consumers (non-Toyota owners) following the Toyota automotive recalls. It was found that there is a significant difference between high-involvement consumers (Toyota owners) than for low-involvement consumers (non-Toyota owners) $(\mathrm{t}=$ $-12.42, \mathrm{df}=229, \mathrm{p}<0.001)$. Toyota owners $(\mathrm{M}=4.28, \mathrm{SD}=0.97)$ report significantly higher 
levels of post-recall purchase intentions with the Toyota brand than the non-Toyota owners $(\mathrm{M}=2.26, \mathrm{SD}=1.17)$. These results show support for $\mathrm{H} 2$, that consumers' purchase intentions towards Toyota are higher for high-involvement consumers than consumers with low levels of involvement following the Toyota automotive recalls.

\subsection{Investor Results}

\subsubsection{Abnormal Returns}

In order to test H3, the author used event-study methodology through the WRDS database to test the various event windows under investigation. Table 2 shows the returns for the date of the recall announcement as well as the returns for suggested event windows in the application of event-study methodology (Deitz, Evans, \& Hansen, 2013). All of the event windows result in negative abnormal returns to the stock price with the exception of the first announcement date and the event window $(0,+1)$ for the third announcement date. The reasons for these exceptions could be the leakage of information prior to the official announcement or that investors had already traded on what they thought was complete information.

Two out of the three announcement dates result in negative abnormal returns to the stock price with the exception of the January 21 recall. Furthermore, event windows $(-3,+3)$ and $(-5,+5)$ produce exclusively negative abnormal returns, and five out of the six windows are significantly negative. These findings show partial support for $\mathrm{H} 3$, investor reaction to each of the Toyota automotive recalls in January 2010 results in negative abnormal returns to the firm's stock price on the trading days surrounding the recall announcements. These findings further support the proposition by Deitz, Evans, \& Hansen (2013) that investor behavior should be examined over various event windows to better understand how investor knowledge prior to and following the recall announcements affects trading behavior.

Table 2. Cumulative Abnormal Returns Event Windows

\begin{tabular}{llll} 
Event Windows & January, 21 & January, 27 & January, 29 \\
\hline Recall Date & $1.09 \%$ & $\underline{\mathbf{- 8 . 1 7 \%}}$ & $-0.97 \%$ \\
$(0,+1)$ & $-1.51 \%$ & $\underline{\mathbf{- 1 0 . 6 8 \%}}$ & $2.70 \%$ \\
$(-1,+1)$ & $-4.18 \%$ & $\underline{\mathbf{- 1 1 . 7 3 \%}}$ & $-0.11 \%$ \\
$(-3,+3)$ & $-5.14 \%$ & $-12.25 \%$ & $\underline{\mathbf{- 1 6 . 9 8 \%}}$ \\
$(-5,+5)$ & $-14.12 \%$ & $\mathbf{- 2 0 . 9 5 \%}$ & $-\mathbf{- 1 8 . 5 8 \%}$ \\
$(-10,+10)$ & $-16.04 \%$ & $-14.16 \%$ & $-15.93 \%$ \\
\hline
\end{tabular}

Italics $=\alpha<0.10$; bold $=\alpha<0.05$; $\underline{\text { underlined }}=\alpha<0.01$; all sig. tests are two tail tests. 


\subsubsection{Buy-and-Hold Abnormal Returns (BHARs)}

Because Van Heerde, Helsen, \& Dekimpe (2007) found that PHCs can jeopardize enduring relationships with the stock and have negative performance consequences that linger long after the crisis, and to test $\mathrm{H} 4$, that investor reaction to the January 2010 Toyota automotive recalls is persistent and results in negative buy-and-hold abnormal returns (BHARs), the event-study methodology buy-and-hold abnormal returns function through WRDS was applied. Results show that in the six months following the announcement of the PHCs, the BHAR showed a $23.53 \%$ decrease in stock price, thus showing support for H4.

\subsection{Combined Results}

In order to test H5, that the Interbrand Brand Equity Index year-over-year measure will decrease for Toyota from 2009 to the end-of-year measure for the year of the recalls, 2010, I use the Interbrand Brand Equity Index. The end of year ranking for 2010 shows that Toyota had fallen from eighth to eleventh place on Interbrand's Top 100 Best Global Brands from their 2009 position (Best Global Brands, 2010). This slide resulted in a loss of $\$ 5$ billion in brand value, or $16 \%$ during the year and accounted for the biggest percentage drop among the top 100 ranked global brands for 2010 (Best Global Brands, 2010). This finding shows support for $\mathrm{H} 5$ that the PHCs have a negative effect on the overall measure designed to capture the combined effect of consumer and investor reactions.

\section{Discussion and Managerial Implications}

\subsection{Consumers}

The marketing literature documents well the understanding of the reactions of consumers to PHCs; however, most of the studies use laboratory settings with fictional products and fictional PHCs. This study provides the opportunity to observe the reactions of actual consumers to real-life PHCs. Further, study shows that those consumers with high-levels of involvement prior to the announcement of the PHCs insulate themselves against negative firm news while those with low-levels of involvement view the firm in a more negative light following the announcements. For Toyota, this finding is demonstrated through the testing of the hypotheses. The tests show that for Toyota owners, their post-PHC attitude toward Toyota and purchase intentions are higher than non-Toyota owners. This is important for managers to understand in building and shaping their marketing communications and management strategy. Because current owners of the brand show relatively no negative reaction to the recalls, firms should focus their strategy on reaching and influencing non-owners rather than reinforcing the attitudes of current owners. By focusing the marketing strategy on non-owners following the recall, it should provide a better opportunity for the firm to change the negative attitudes of this group.

Further, the average length of ownership is longer for Toyota owners with 59\% owning their vehicle for more than three years, while only $40 \%$ of non-Toyota owners own their vehicle for more than three years (see Figure 2). Also, $79 \%$ of Toyota owners and $52 \%$ of non-Toyota 


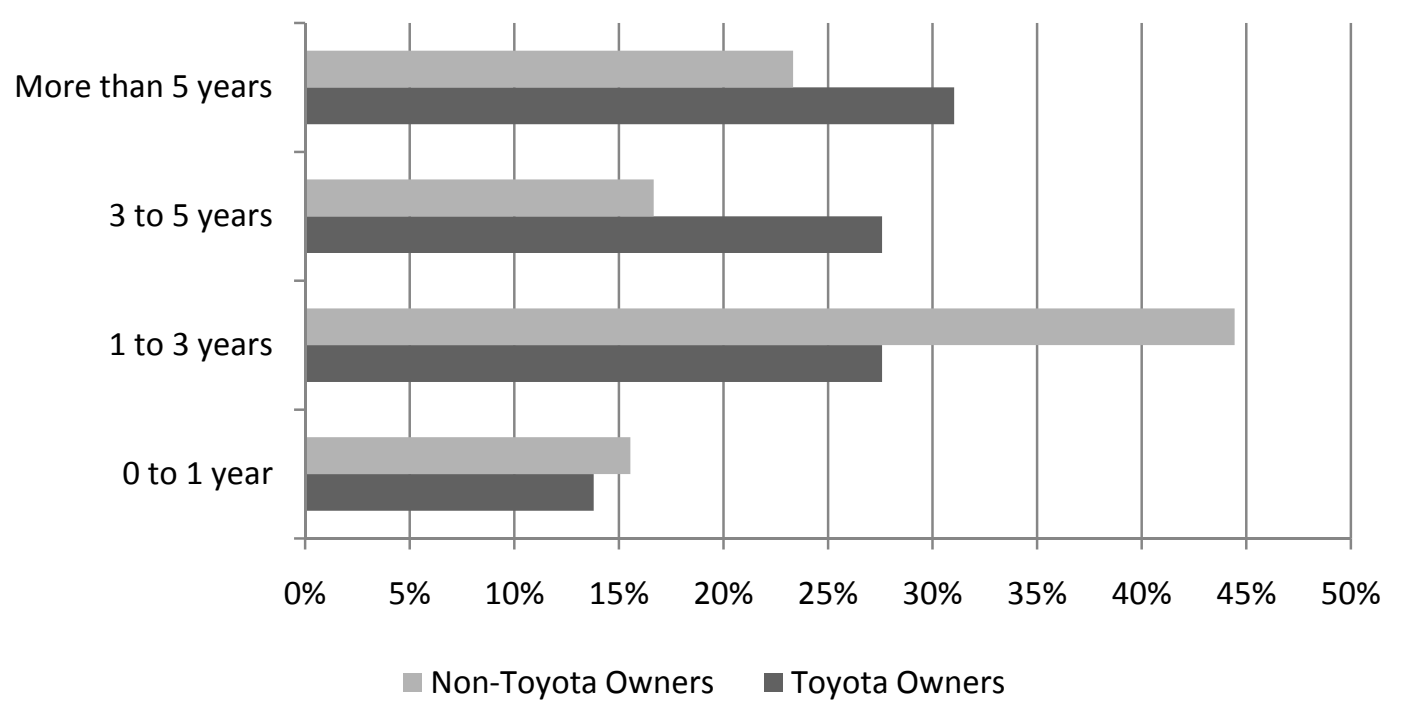

Figure 2. Length of Ownership, Toyota and Non-Toyota Owners

owners are two or more years away from the anticipated purchase of a new vehicle (see Figure 3). These findings demonstrate that Toyota owners purchase less frequently, and when they do purchase, they have a tendency to hold-on to their vehicles longer. As stated above, the true challenge seems to be following a PHC where the management of the non-users of a product is more important than the management of users. As such, Toyota, and other firms faced with a PHC, should make direct attempts to reach and influence those potential consumers. These attempts can be done through the incentivization of current non-users. Whether the incentivization is financial such as rebates, special financing, extended financing, etc. or nonfinancial such as offering upgrades on the vehicle; the firm must make a connection with the non-user.

The firm at the center of a PHC must be aware of and directly tackle the competition's attempts to take advantage of the firm's PHC. For example, directly following the announcement of the Toyota PHCs, General Motors, Ford Motor Company, and Hyundai sought to take advantage of the situation by offering Toyota owners an additional $\$ 1,000$ towards the purchase of one of their products to trade in their vehicle (CNN Money, 2010). Although $\$ 1,000$ might seem trivial for such a large purchase, the gesture could influence those current owners who have a lower level of loyalty. Although the competition's attempts cannot be stopped, the firm must manage their response to these actions in a way that negates the effect of competitive firm behavior. 


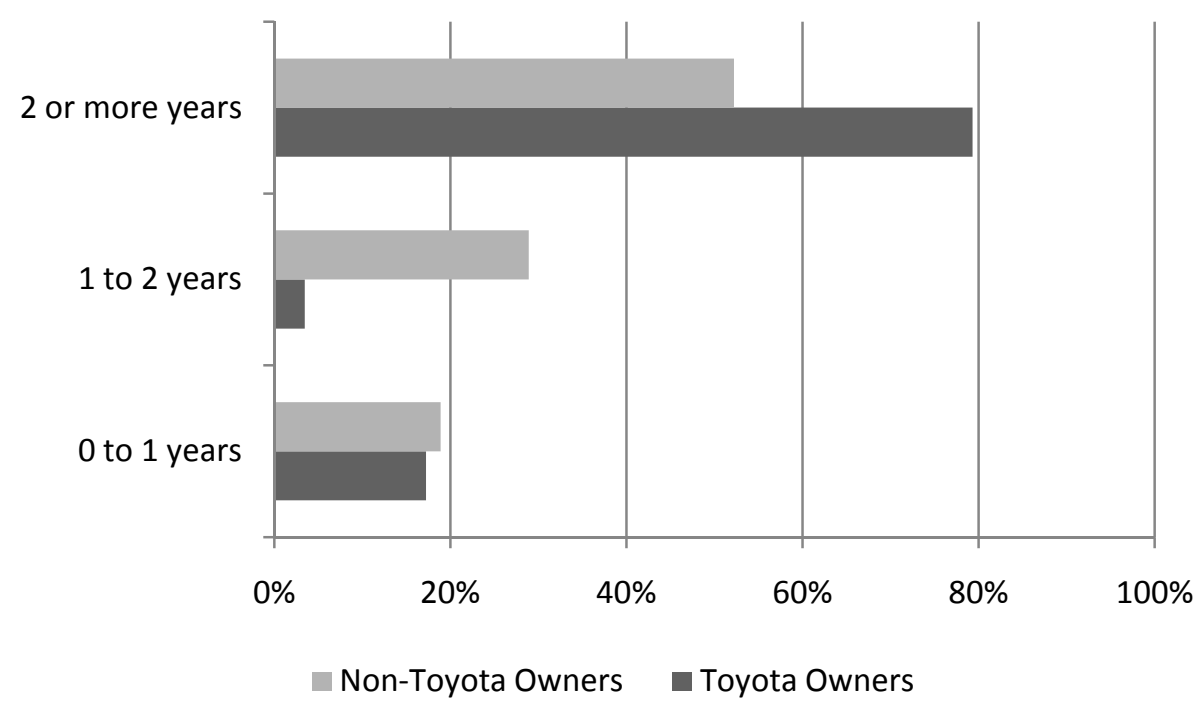

Figure 3. Length until Purchase of Next Vehicle

\subsection{Investors}

Insulating your firm from the negative effects of a $\mathrm{PHC}$ is difficult, if not impossible, as the PHC relates to investors. Investors tend to trade based upon their current knowledge of the firm and their individual risk tolerances, many times ignoring the brand value of a firm or the positive past performance. In the case of the PHC, the firm needs to actively publicize their attempts to correct the problem; report accurate and up-to-date sales figures; and continue to make known information on the resultant effects of the PHC on their financial bottom-line.

For firms with multiple announcements relating to a PHC such as Toyota, consideration should be made to make all PHC knowledge available at one time, rather than leaking out individual PHC announcements. This action might ameliorate the damage to the stock price and shareholder wealth. Coordination of these efforts also must take place worldwide; many firms operate in many markets, and their stock is often traded on exchanges outside the United States. Finally, in an effort to manage investor relationships, firms should actively pursue a media campaign that reaches financial publics because they seem to be the ones that react the most quickly, and harshly, to a PHC, penalizing firms with losses to shareholder value and declines in stock price.

\subsection{Combined Results}

To the author's knowledge, this is the first study that seeks to measure the combined effect of a PHC on consumers and investors. Therefore, because of the different implications for management of these two groups post PHC, firms should consider the managerial implications and actions discussed in this study. Because Toyota lost $16 \%$ of its brand equity in the year of the PHC announcements as measured by the Interbrand Brand Equity Index, firm managers should concentrate on long-term measures to ensure the financial health and stability of the firm. The CEOs and others with a fiduciary responsibility should be incentivized to operate with short- and long-term interests of the firm in mind. Because 
consumers and investors can both contribute to the success of the firm, serving both parties is important. Overall, the efforts to reach the consumer as well as the investor should be coordinated in a manner as to provide each group with appropriate and timely information.

\section{Future Research}

Future research on the consumer and the investor in relation to PHCs should strive to examine the effects on these groups in real versus laboratory settings. As most events, especially PHCs, are difficult to predict, the researcher should also seek to examine users and non-users of the product under investigation in order to form a comparison of those who may exhibit a higher level of involvement relative to others. The examination of these two groups in real situations could contribute to the literature by showing actual effects to the firm through consumer and investor behavior.

Additionally, striving to find a generally accepted measure designed to capture consumer and investor behavior could benefit the marketing literature. The future research should seek to focus on the development of this measure. As literature relating to the marketing-finance interface becomes more accepted, this measure should serve to better inform managers of the aggregated effects of events and decisions on the firm's value from not just the consumer or investor perspective, but, from a holistic, practical viewpoint.

\section{References}

Agrawal, J., \& Kamakura, W. (1995). The economic worth of celebrity endorsers: an event study analysis. The Journal of Marketing, 59(3), 56-62. http://dx.doi.org/10.2307/1252119

Antil, J.H. (1984). Conceptualization and operationalization of involvement. In T.C. Kinnear (Ed.), Advances in Consumer Research, 11(1), 203-209. Provo, UT: Association for Consumer Research.

Bharadwaj, S.G., Tuli, .KR., \& Bonfrer, A. (2011). The impact of brand quality on shareholder wealth. Journal of Marketing, 75(5), 88-104. http://dx.doi.org/10.1509/jmkg.75.5.88

Bloch, P.H., Sherrell, D.L., \& Ridgway, N.M. (1986). Consumer search: An extended framework. Journal of Consumer Research, 13(1), 119-126. http://dx.doi.org/10.1086/209052

Brown, S.J., \& Warner, J.B. (1985). Using daily stock returns: The case of event studies. Journal of Financial Economics, 3-31. http://dx.doi.org/10.1016/0304-405X(85)90042-X

Carlston, D.E., \& Skowronski, J.J. (2005). Linking versus thinking: evidence for the different associative and attributional bases of spontaneous trait transference and spontaneous trait inference. Journal of Personality \& Social Psychology, 89(6), 884-898. http://dx.doi.org/10.1037/0022-3514.89.6.884 
Chen, Y., Ganesan, S., \& Liu, Y. (2009). Does a firm's product-recall strategy affect its financial value? An examination of strategic alternatives during product-harm crises. Journal of Marketing, 73(6), 214-226. http://dx.doi.org/10.1509/jmkg.73.6.214

Churchill Jr., G.A., \& Surprenant, C. (1982). An investigation into the determinants of customer satisfaction. Journal of Marketing Research, 19(4), 491-504. http://dx.doi.org/10.2307/3151722

Collier, J.E., \& Sherrell, D.L. (2010). Examining the influence of control and convenience in a self-service setting. Journal of the Academy of Marketing Science, 38(4), 490-509. http://dx.doi.org/10.1007/s11747-009-0179-4

Cornwell, T.B., Pruitt, S.W., \& Clark, J.M. (2005). The relationship between major-league sports' official sponsorship announcements and the stock prices of sponsoring firms. Journal of the Academy of Marketing Science, 33(4), 401-412. http://dx.doi.org/10.1177/0092070305277385

Dawar, N., \& Pillutla, M.M. (2000). Impact of product-harm crises on brand equity: the moderating role of consumer expectations. Journal of Marketing Research, 37(2), 215-226. http://dx.doi.org/10.1509/jmkr.37.2.215.18729

Deitz, G.D., Evans Jr., R.D., \& Hansen, J. (2013). Sponsorship and shareholder value: A re-examination and extension. Journal of Business Research, 66(9), 1427-1435. http://dx.doi.org/10.1016/j.jbusres.2012.05.010

Engle, J.R., \& Blackwell, R.D. (1982). Consumer Behavior. (4th ed.), Chicago: The Dryden Press.

Evans Jr., R.D. (2010). The effects of official sports sponsorship on firm market liquidity and risk. A doctoral dissertation, University of Memphis.

Fama, E.F. (1965). The behavior of stock market prices. Journal of Business, 38(1), 34-105. http://dx.doi.org/10.1086/294743

Eugene F. Fama. (1970). Efficient capital markets: a review of theory and empirical work. Journal of Finance, 25(2), 383-417. http://dx.doi.org/10.2307/2325486

Eugene F. Fama. (1980). Agency problems and the theory of the firm. Journal of Political Economy, 88(2), 288-307. http://dx.doi.org/10.1086/260866

Haas-Kotzegger, U. \& Schlegelmilch, B.B. (2013). Conceptualizing consumers' experiences of product-harm crises. Journal of Consumer Marketing, 30(2), 112-120. http://dx.doi.org/10.1108/07363761311304924

http://money.cnn.com/2010/01/29/autos/gm_hyundai_toyota_incentives, retrieved July 23, 2014.

http://web.archive.org/web/20061130225009/, retrieved July 18, 2014.

http://www.rtnda.org/members/communicator/totalrecall.asp, retrieved July 10, 2014. 
http://www.businessweek.com/news/2010-02-02/toyota-sales-drop-may-mean-tough-monthsahead-on-recall-crisis.html, retrieved August 20, 2014.

http://www.esopro.com/erp-blog/industry-musings/the-10-most-disastrous-product-recalls-ofall-time, retrieved July 10, 2014.

http://www.interbrand.com/en/best-global-brs/previous-years/best-global-brands-2009.aspx, retrieved February 10, 2014.

http://www.interbrand.com/en/knowledge/best-global-brands/best-global-brands-2008/best-gl obal-brands-2010.aspx, retrieved February 11, 2014.

http://www.sptimes.com/News/webspecials/firestone/timeline.shtml, retrieved July 10, 2014.

Jack, E.P., \& Powers, T.L. (2013). Shopping behaviour and satisfaction outcomes. Journal of Marketing Management, 29(13-14), 1609-1630. http://dx.doi.org/10.1080/0267257X.2013.798678

Jain, K., \& Srinivasan, N. (1990). An empirical assessment of multiple operationalizations of involvement. Advances in Consumer Research, 17(1), 594-602.

Kalaignanam, K., Kushwaha, T., \& Eilert, M. (2013). The impact of product recalls on future product reliability and future accidents: evidence from the automobile industry," Journal of Marketing, 77(2), 41-57. http://dx.doi.org/10.1509/jm.11.0356

Kaniel, R., Liu, S., Saar, G., \& Titman, S. (2012). Individual investor trading and return patterns around earnings announcements. Journal of Finance, 67(2), 639-680. http://dx.doi.org/10.1111/j.1540-6261.2012.01727.x

Krystek, U. (1987). Unternehmungskrisen, Wiesbaden: Gabler, p. 6.

Lowe, B., \& Barnes, B.R. (2012). Consumer perceptions of monetary and nonmonetary promotions for new products. Journal of Marketing Management, 28(5-6), 629-651. http://dx.doi.org/10.1080/0267257X.2011.560889

Lubatkin, M.H., Chung, K.H., \& Rogers, R.C. (1989). Stockholder reactions to CEO changes in large corporations. Academy of Management Journal, 32(1), 47-68. http://dx.doi.org/10.2307/256419

Luo, X., \& Bhattacharya, C.B. (2009). The debate over doing good: corporate social performance, strategic marketing levers, and firm-idiosyncratic risk. Journal of Marketing, 73(6), 198-213. http://dx.doi.org/10.1509/jmkg.73.6.198

Markovitch, D.G., \& Golder, P.N. (2008). Findings - Using stock prices to predict market events: evidence on sales takeoff and long-term firm survival. Marketing Science, 27(4), 717-729. http://dx.doi.org/10.1287/mksc.1070.0325

Mittal, V., Dholakia, U.M., \& Sambandam, R. (2010). Toyota steers clear of reputation damage. Marketing Research, 22(2), 9-13. 


\section{Macrothink}

Journal of Management Research

ISSN 1941-899X

2015, Vol. 7, No. 5

Reibstein, D.J., Day, G., \& Wind, J. (2009). Guest editorial: Is marketing academia losing its way?," Journal of Marketing, 73(4), 1-3. http://dx.doi.org/10.1509/jmkg.73.4.1

Rhee, M., \& Haunschild, P.R. (2006). The liability of good reputation: A study of product recalls in the U.S. automobile industry. Organization Science, 17(1), 101-117. http://dx.doi.org/10.1287/orsc.1050.0175

Shimp, T.A., \& Sharma, S. (1987). Consumer ethnocentrism: Construction and validation of the CETSCALE. Journal of Marketing Research, 24(3), 280-289. http://dx.doi.org/10.2307/3151638

Stafford, T.F. (2000). Alert or oblivious? Factors underlying consumer responses to $\begin{array}{llll}\text { marketing stimuli. Psychology \& } \quad \text { Marketing, } 17(9), & \text { 745-760. }\end{array}$ http://dx.doi.org/10.1002/1520-6793(200009)17:9\%3C745::AID-MAR1\%3E3.3.CO;2-U

Suh, J. \& Youjae, Y. (2006). When brand attitudes affect the customer satisfaction-loyalty relation: The moderating role of product involvement. Journal of Consumer Psychology, 16(2), 145-155. http://dx.doi.org/10.1207/s15327663jcp1602_5

Van Heerde, H., Helsen, K., \& Dekimpe, M.G. (2007). The impact of a product-harm crisis on marketing effectiveness. Marketing Science, 26(2), 230-245. http://dx.doi.org/10.1287/mksc.1060.0227

Woodside, A.G., \& Waddle, G.L. (1975). Sales effects of in-store advertising. Journal of Advertising Research, 15(3), 29-33.

Zaichkowsky, J.L. (1985). Measuring the involvement construct. Journal of Consumer Research, 12(3), 341-352.

Zhao, Y., Zhao, Y., \& Helsen, K. (2011). Consumer learning in turbulent market environment: modeling consumer choice dynamics after a product-harm crisis. Journal of Marketing Research, 48(2), 255-267. http://dx.doi.org/10.1509/jmkr.48.2.255 